\title{
RESEARCH ON CONSUMER COMMITMENT TO ORGANIC FOOD IN SOUTHERN RUSSIA
}

\author{
V. Trukhachev, E. Epimakhova, E. Rastovarov \\ Technological Management Faculty, Stavropol State Agrarian University, \\ Stavropol, Russia \\ V. Ivashova \\ Economic Faculty, Stavropol State Agrarian University, Stavropol, Russia
}

\begin{abstract}
This article is devoted to the study of the attitude to organic food of residents of Southern Russia in connection with the development of a regional model of organic animal husbandry. Respondents consider organic products more acceptable to be healthy. Since the Russian state must take care of the health of the nation, the development of organic production and the consumption of environmentally friendly products by the population is, above all, the responsibility of the state. According to survey participants, it affects such areas as price control for these types of products and targeted programs to support producers, whose activities meet the needs and expectations of consumers. An important role is played by knowledge and skills of managers and employees of agricultural organizations to increase the efficiency of production and sales of organic livestock and poultry products. Therefore, professional (re)training and professional development through special programs are relevant to achieve this.
\end{abstract}

Key words: organic livestock production; regional production model; sociological survey.

Cite this Article: V. Trukhachev, E. Epimakhova, V. Ivashova, E. Rastovarov, Research on Consumer Commitment to Organic Food in Southern Russia, International Journal of Management, 10 (2), 2019, pp. 145-153.

http://iaeme.com/Home/issue/IJM?Volume=10\&Issue $=2$

\section{INTRODUCTION}

According to WHO, only $5 \%$ of people's health depends on physical health, $20 \%$ on genetics, $25 \%$ on environmental conditions, and $50 \%$ on proper and healthy nutrition.

Quality of food refers to a set of characteristics of food products that meet the stated requirements and include its safety, consumer properties, energy and nutritional value, authenticity, ability to meet human needs for food under normal conditions of use in order to ensure the preservation of human health. The state of food products is recognized as safe, indicating that there is no risk associated with harmful effects on humans and future generations. The value of products (energy and food) characterizes the presence and 
quantitative content of food and minor biologically active substances in it that determine the biological and physiological value, caloric content and digestibility. The daily need of a working person covers the consumption of at least three types of products from the groups "milk", "meat", "fish", "cereals", "legumes", "seeds", "nuts" and "vegetables". For example, 75 grams of lean pork, 100 grams of salmon and 0.5 liters of milk.

In this regard, the development of organic or natural agricultural production occupies a significant place. The benefits of products of which are now recognized by science, consumers and authorities as safe and which fit perfectly into the structure of nutrition of modern mankind.

Organic farming is a global brand. Organic products in many countries around the world make up to $20 \%$ of the sales volume and about $\$ 100$ billion worldwide. Over the past 15 years the market of organic (ecological) products has been grown 500\%. Ecological (organic) agriculture is practiced in 179 countries of the world, but only 87 of them have a regulatory framework for this field of activity. The largest national markets are the USA (\$ 36 billion per year), Germany - $\$ 10.5$ billion, and France - $\$ 6.8$ billion. The highest consumption of organic products per capita in European countries. The Russian organic market today is $\$ 120$ million, or $€ 160$ million. $90 \%$ of certified products on domestic shelves are imported in Russia.

The breakdown of the potential domestic market is as follows: $80 \%-$ Moscow, $10 \%-\mathrm{St}$. Petersburg, $10 \%$ - the rest of the million-plus cities. The breakdown of potential consumers: $45 \%$ - young mothers and young children, $30 \%$ - followers of healthy lifestyles, $10 \%$ - allergies, $10 \%$ - people with high incomes. According to industry experts, the most significant profits in the organic sector are those producers who managed to create a full-cycle production, including the processing of products. At the same time, marginality may exceed traditional production by $80 \%$.

\section{LITERATURE REVIEW}

Organic agriculture is a set of economic activities where the implementation of different methods and technologies are used, aiming to ensure a favorable state of the environment to keep productive animals, improving human health by using products with specified quality parameters, and to preserve and restore soil fertility. Examples of the successful development of organic livestock and poultry are available throughout the world and in several regions of Russia. The most significant profits in the organic sector are those producers who managed to create a full-cycle production, including the processing of products.

"Organic" livestock and poultry farming in the EU since 2000 must meet the criteria of Animal Welfare (Directive 1999/74 EC). The unified labeling of organic (ecological) products in the EU in recent years has been a "europlayer".

Iweala S., Spiller A., Meyerding S. present the results of an empirical analysis of preferences according to a representative survey of consumers in the UK $(n=452)$ and Germany $(\mathrm{n}=465)$. The analysis proves that in both cases, food markets with ethical requirements are quite mature, but with varying degrees of pro-social and pro-ecological requirements. Higher ethical requirements are noted in Germany, compared with the UK. It was noted that labeling is a prerequisite for the development of ethical requirements for products and an important factor for marketing strategies in order to increase the sale of food with socially significant characteristics [8].

According to a survey conducted by Yin S., Hu W., Chen Y., Wang Y., Chen M. in the Chinese province of Shandong, consumer preferences and their willingness to pay for organic tomatoes are higher than those of similar unmarked products. In addition, consumers prefer brands owned by private enterprises, and agricultural cooperatives. This is due to the limited shelf life, small production volumes and quality of natural products [21]. 
The advantages and disadvantages of organic production are relevant not only for the agricultural production of the food industry, but also for the processing industry, as evidenced by studies by Zahedipour P., Asghari M., Abdollahi B., Alizadeh M., Danesh Y.R. It is established that the shelf life and market value of grapes (Vitis vinifera cv. Thompson seedless) during storage is closely related to the systems of its cultivation. Organic berries showed more desirable color parameters, higher antioxidant enzyme activity and a lower browning index than normal ones. At the same time, lower moisture loss and decay index, as well as higher resistance, were observed in ordinary berries [22].

Although many factors exert an influence on consumer preferences, one should not disregard the appearance of the so-called Millennials. Millennials (people born between the beginning of the 80 s and the beginning of the 2000s) are replacing the aging "baby boomers" (born after the Second World War and before the beginning of the 60s) from their business activity. As consumers, millennials have their own particular tastes and preferences, which are very different from the priorities of previous generations. Taking care of their health and wellbeing has become a familiar part of their daily worries, while they do not like to "go" on a diet. They prefer what they consider a healthy choice. They want to eat better, love fresh food and are willing to spend more on food. Food becomes part of Millenial identification and life experience. They want to know the whole chain of food production and its environmental friendliness.

For purposeful and scientifically grounded production of organic food in the south of Russia, it has become necessary to develop a regional model of organic animal husbandry. In this regard, the purpose of this work is a comprehensive analysis of opinions of consumer to information and to give analytical support for the development of a regional model of organic food.

\section{METHODS AND MATERIAL}

The sociological study "Attitude of the population of the Stavropol Territory to food products" was conducted in 2018 using a questionnaire survey. A total of 235 people took part in the survey.

Analysis of the socio-demographic characteristics of the surveyed population shows that among the respondents $59.7 \%$ were women and $40.3 \%$ were men, which is close to the actual ratio of residents of the region by sex. $57.9 \%$ of respondents live in cities, $34.0 \%$ - in villages, $7.2 \%$ - in urban-type settlements, $0.9 \%$ - on a farm. $35.6 \%$ of respondents have higher education, $53.4 \%$ - incomplete higher education, $11.0 \%$ - general secondary. $63.8 \%$ of respondents are representatives of families with $1-2$ children; $10.3 \%$ belong to larger families; $14.3 \%$ of respondents are representatives of single-parent families; $6.7 \%$ - fall into the category of "young families" (one of the spouses is under 30); an insignificant share of respondents fall into the category of non-working pensioners $-3.6 \%$ and people with disabilities $-1.3 \%$.

In terms of income per family member, the surveyed population is characterized as follows: $11.0 \%$ of respondents have up to 6,000 rubles per person; from 6,000 to 10,000 rubles $-38.2 \%$ of respondents; from 10,000 to 15,000 rubles $-29.1 \%$; more than 15,000 rubles $-20.7 \%$ of respondents. In general, it can be observed that the financial situation of survey participants is satisfactory and good.

According to the survey, almost a third of respondents (34.5\%) spend $40 \%$ to $50 \%$ of their income on food purchases. $19.3 \%$ of respondents spend $30 \%$ to $40 \%$ of the monthly income on food purchases. $17 \%$ of respondents $-50 \%$ to $60 \%$. $14.3 \%$ of respondents $-20 \%$ to $30 \%$. An insignificant share of survey participants indicated extreme costs for the purchase of food products: either extremely large or extremely small. $6.3 \%$ of respondents spend up to $20 \%$ of 
monthly income on food; $5.8 \%$ of respondents spend $60-70 \%$ of the family budget on food and $2.8 \%$ of respondents spend more than $70 \%$ of the budget on food.

Respondents are responsible for housekeeping. The following information is entered in the business register: characteristics of the land plot (62.2\%); livestock number $(46.7 \%)$; the number of perennial plantations (16.7\%); list of agricultural machinery $(12.2 \%)$; data on the production and sales of products (respectively $16.7 \%$ and $11.1 \%$ ).

As part of the survey, residents of the South of Russia expressed their opinion on the quality and safety of food (table 1).

Table 1 Distribution of answers to the question: "Are the quality and safety of food products that you and / or your family are purchasing? (\%)

\begin{tabular}{|l|c|c|c|c|c|c|c|}
\hline \multirow{2}{*}{ Answers } & \multicolumn{2}{|c|}{$\begin{array}{c}\text { Place of } \\
\text { residence }\end{array}$} & \multicolumn{2}{c|}{ Education } & \multicolumn{2}{c|}{$\begin{array}{c}\text { Are you a product } \\
\text { producer? }\end{array}$} & \multirow{2}{*}{ Total } \\
\cline { 2 - 7 } & $\begin{array}{c}\text { villag } \\
\text { e }\end{array}$ & city & $\begin{array}{c}\text { without } \\
\text { higher } \\
\text { education }\end{array}$ & $\begin{array}{c}\text { higher } \\
\text { education }\end{array}$ & yes & no & 21,1 \\
\hline Fully satisfied & 21,2 & 21,3 & 26,4 & 9,0 & 21,9 & 21,3 \\
\hline $\begin{array}{l}\text { Partially } \\
\text { satisfied }\end{array}$ & 55,5 & 62,5 & 53,6 & 71,8 & 53,1 & 59,1 & 59,6 \\
\hline $\begin{array}{l}\text { Absolutely not } \\
\text { satisfied }\end{array}$ & 10,1 & 8,1 & 8,6 & 9,0 & 9,4 & 9,4 & 8,9 \\
\hline $\begin{array}{l}\text { I did not think } \\
\text { about it }\end{array}$ & 8,1 & 5,9 & 8,6 & 5,1 & 6,2 & 7,6 & 6,8 \\
\hline I do not care & 5,1 & 2,2 & 2,8 & 5,1 & 9,4 & 2,8 & 3,4 \\
\hline
\end{tabular}

With a fairly large expenditure on food purchases ( $40 \%$ or more), only one out of every five respondents is completely satisfied with the quality and safety. $59.6 \%$ are only partially satisfied with the quality and safety of products; $8.9 \%$ - absolutely not satisfied; $6.8 \%$ did not think about it; $3.4 \%$ answered that they do not care. Interestingly, respondents with higher education expressed a greater degree of dissatisfaction with the quality and safety of food.

More than half of the survey participants $(54.7 \%)$ indicated the see 'sometimes' food which is labeled "bio," "eco," or “organic." 'Often', only $10.3 \%$ of respondents gave such indications. $9.4 \%$ said they never see those. A high proportion (23.5\% of respondents) do not pay attention to such marking at all. Whilst $1.7 \%$ of the respondents are specifically looking for such a label. Positive is that only about $0.4 \%$ of respondents are ignorant about the meaning of this label.

Despite the fact that in the survey a large proportion of the participants are 20-30-year-old residents of the South of Russia and who grew up in the existing conditions of market relations and with certain consumer expectations - their understanding of the label "bio", "eco" or "organic" on food is very blurred (table2).

Table 2 Distribution of answers to the question: "What, in your opinion, does" bio ", "eco "or" organic "labeling mean on food? (\%)

\begin{tabular}{|l|c|c|c|c|c|c|c|}
\hline \multirow{2}{*}{ Answers } & \multicolumn{2}{|c|}{$\begin{array}{c}\text { Place of } \\
\text { residence }\end{array}$} & \multicolumn{2}{c|}{ Education } & \multicolumn{2}{c|}{$\begin{array}{c}\text { Are you a product } \\
\text { producer? }\end{array}$} & \\
\cline { 2 - 7 } & село & village & $\begin{array}{c}\text { without } \\
\text { higher } \\
\text { education }\end{array}$ & $\begin{array}{c}\text { higher } \\
\text { education }\end{array}$ & yes & no & Total \\
\hline $\begin{array}{l}\text { No artificial } \\
\text { additives }\end{array}$ & 26,3 & 41,9 & 39,3 & 29,5 & 31,3 & 36,8 & 35,3 \\
\hline $\begin{array}{l}\text { No harmful } \\
\text { substances }\end{array}$ & 26,3 & 21,3 & 22,9 & 24,4 & 25,0 & 24,6 & 23,4 \\
\hline
\end{tabular}




\begin{tabular}{|l|c|c|c|c|c|c|c|}
\hline Useful for health & 7,1 & 11,8 & 10,0 & 9,0 & 3,1 & 10,5 & 9,8 \\
\hline $\begin{array}{l}\text { Grown in an } \\
\text { ecologically clean } \\
\text { place }\end{array}$ & 31,3 & 40,4 & 33,6 & 39,7 & 37,5 & 35,1 & 36,6 \\
\hline $\begin{array}{l}\text { Producer's } \\
\text { advertising tool }\end{array}$ & 17,2 & 14,0 & 13,6 & 17,9 & 18,8 & 13,5 & 15,3 \\
\hline $\begin{array}{l}\text { I did not think } \\
\text { about it }\end{array}$ & 15,2 & 2,9 & 5,7 & 10,3 & 9,4 & 8,8 & 8,1 \\
\hline
\end{tabular}

Just over a third of survey participants $(36.6 \%)$ believe that such labeling show an ecologically clean place where raw materials for food production are grown. Almost as many survey participants (35.3\%) believe that labeling is an evidence of no added artificial additives in food. In the understanding of $23.4 \%$ of respondents, no harmful substances are in the products. $15.3 \%$ of respondents believe that the label "bio", "eco" or "organic" has no relation to the quality of products. $9.8 \%$ of respondents believe that such a labeled product is good for their health and $8.1 \%$ of respondents did not even think about this issue.

There is no fundamental difference in the responses of respondents over the segmentation groups. At the same time, people in rural areas thought less about the meaning of labeling than other categories of the population.

Despite the vagueness of labeling, about half of them regularly buy organic or natural products for the whole family $-52.8 \%$ of respondents. $41.2 \%$ of respondents do this extremely rarely and $6.0 \%$ never buy.

Supermarkets are the most common place to buy organic (natural) food for residents of the South of Russia. The ranking of responses is presented in Figure 1.

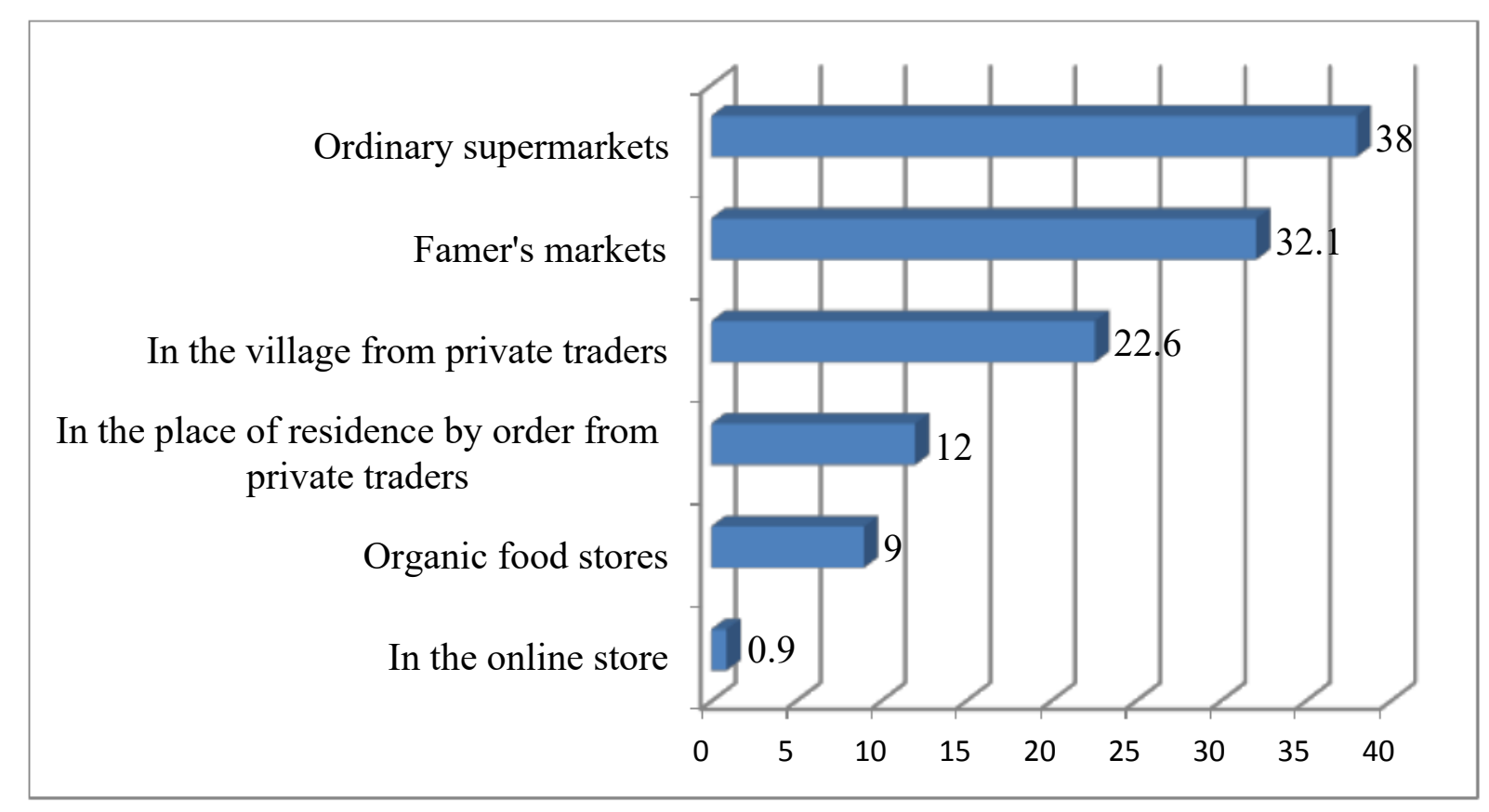

Figure 1 Ranking of answers to the question: "Where do you usually buy organic products?" (\%)

At the same time, considering that $32.1 \%$ of respondents purchase organic (natural) products from farmers' markets, $22.6 \%$ of respondents in villages from private owners and $12 \%$ of respondents also from private owners, only a minority uses the organized trading networks.

The segmentation data of the respondents show the following differences in strategies for acquiring organic products: 
- - If, in the whole surveyed population, organic products are bought at private residence by $12.0 \%$ of respondents, then $23.2 \%$ use this strategy among rural residents and $22.1 \%$ among respondents with higher education;

- - orientation towards the purchase of organic products in supermarkets is more characteristic for respondents living in cities and those who do not have a higher education;

- - Organic products are purchased at farmers' markets in more than $50 \%$ of the surveyed population of citizens, respondents with higher education and commodity producers;

- - Commodity producers and villagers are attracted by rural private owners, choosing a place to purchase organic products.

The ranking of the reasons for choosing organic food showed that safety and health is ranked first, high quality ranked second and product freshness ranked third. The good taste has a fourth place, lack of confidence in common products is ranked fifth, and the two last places are occupied by reasons as improvement of living conditions of animals and supporting local producers.

Most respondents believe that the state should take care of the health of the nation and therefore the development of organic production and the consumption of environmentally friendly products by the population is, first and foremost, the responsibility of the state. Moreover, of all the groups allocated within the framework of segmentation, the group of producers largely adheres to this opinion. If on average, according to the surveyed population, the option "the state should take care of the health of the nation" was noted by $49.4 \%$ of respondents, then in the group "producers," $53.1 \%$ of the respondents chose this option.

According to half of the survey participants from among the Stavropol Territory residents, the question of increasing the organic food production in the region is now overdue $(27.4 \%)$ and promising $(24.4 \%)$. Thus, respondents expressed a positive assessment of the prospects to expand the production and sale of organic food.

At the same time, almost half of the respondents noted the unreadiness to expand the Russian market of organic food products: the "no" option was noted by $10.7 \%$ of survey participants; the option "most likely not, maybe, production and sales will expand later" $-27.4 \%$ of survey participants; the option "hardly the demand is too small" - $10.1 \%$ of survey participants.

The ranking of possible actions that, according to survey participants, can positively influence the development of the organic food production market in the region, shows that the first place is occupied by the ban on the use of pesticides, stimulants: $36.3 \%$ of respondents answered - GMOs. $2^{\text {nd }}$ place - state subsidies producers of organic products $(35.9 \%) .3^{\text {rd }}$ place - the promotion of healthy nutrition $(26.6 \%) .4^{\text {th }}$ place - the implementation laws and clear standards in the Russian Federation for the certification of organic products (19.7\%). $5^{\text {th }}$ place - informing the population about the benefits of organic products (16.3\%).

The most promising factor, according to survey participants, to increase the development of the production of organic products are animal husbandry $(66.0 \%)$; crop production $(48.1 \%)$. To a lesser extent, survey participants see the need for the development of aquaculture $(8.5 \%)$ and beekeeping (7.2\%). The prospects for aquaculture development are seen mostly by respondents with higher education ( $11.7 \%$ of respondents with higher education) in relation to the entire surveyed population ( $8.5 \%$ of all survey participants) and respondents who do not have higher education ( $5.7 \%$ of respondents without higher education).

In the course of data analysis, it was recognized that respondents from among rural residents and representatives with higher education see as the most significant problem impeding the development of organic food, the absence or insufficient support from the state (respectively $52.0 \%$ and $56.6 \%$ of specified categories). As an opinion significantly deviating from the 
average for the surveyed population, it should be noted that producers of the denial of such a problem as "a long period of transition to organic production" as a serious obstacle to the development of this area of agriculture.

The problems of developing the production of organic raw materials and food products in the area of the Stavropol Territory, the largest and most economically developed region of southern Russia, are their relatively low demand due to higher prices; unreliable information about the origin; insufficient support and control by the state. In addition, the limited material and technical resources for upgrading premises and equipment, the acquisition of safe and highquality feed are palpable on farms; low level of professional skills and abilities, poor cooperation and logistics.

\section{CONCLUSIONS}

With sufficiently large expenditures in the budget structure of families of residents of the South of Russia for food, only every fifth person is completely satisfied with the quality and safety of the purchased food. A greater dissatisfaction about the quality and safety of food products was expressed by respondents with higher education.

The survey participants' understanding of the labeling "bio", "eco" or "organic" on food is quite vague and low. It was found that people in rural areas thought less about the meaning of labeling than other categories of the population. Despite the vagueness of labeling, about half of them regularly buy organic or natural products for the whole family $-52.8 \%$ of respondents. $41.2 \%$ of respondents do this extremely rarely and $6.0 \%$ never buy.

Residents in the South of Russia prefer organic products because they consider that safety and health, the high quality of these products, their freshness and taste are important to them.

The most significant arguments that may affect the purchase of organic products by the people are: a decline in prices by $20-30 \%$ (1st place); the presence of organic products in the places of my usual grocery shopping (2nd place); detailed information on the composition and production of food ( $3 \mathrm{rd}$ place). Thus, we are talking about the right pricing policy, the wide availability of this category of food and properly organized outreach and possibly affordable social advertising of organic products.

The majority of respondents believe that the state should take care of the health of the nation. Therefore the development of organic production and the consumption of environmentally friendly products by the population is, first and foremost, the responsibility of the state, affecting such areas as price control for these types of products and targeting programs to support producers. This to meet the needs and expectations of consumers.

The prospect of successful development of production and turnover of organic livestock and poultry products at the regional level is to:

- develop a state program;

- unite producers;

- voluntary certification and labeling of products, including expert assessment of the content and state of animal health;

- Quality and safety of the products obtained, its storage, transportation, sale as well as in the development of an information system of its relevance and traceability.

The fundamental element of the vertically integrated structure of the "Regional Model for Organic Livestock and Poultry Farming" is the federal and regional authorities, the Ministry of Agriculture of the Russian Federation and the Stavropol Territory, and the regional branch of the National Organic Union. Potential producers of organic livestock and poultry products in the Stavropol Territory may be, in the first place, small forms of management. At the same 
time, it is more effective for them to unite to development entrepreneurial activity in accordance with the regulatory and legal framework of the Russian Federation and lobbying their interests in the domestic and foreign market for agricultural products. Of great importance for improving the efficiency of production and marketing of organic livestock and poultry products are the knowledge and skills of managers and employees in agricultural organizations. To achieve this, professional training and advanced training in special programs is sufficient

\section{REFERENCES}

[1] Biermann, G., Geist, J. Life cycle assessment of common carp (Cyprinus carpio L.) - A comparison of the environmental impacts of conventional and organic carp aquaculture in Germany Aquaculture 501, 2019, pp 404-415

[2] Choi, S., Seo, H.-S., Lee, K.R., Lee, J., Lee, J. Effect of milling and long-term storage on volatiles of black rice (Oryza sativa L.) determined by headspace solid-phase microextraction with gas chromatography-mass spectrometry Food Chemistry 276, 2019, pp 572-582

[3] Dekani, L., Johari, S.A., Joo, H.S. Comparative toxicity of organic, inorganic and nanoparticulate zinc following dietary exposure to common carp (Cyprinus carpio) Science of the Total Environment 656, 2019, pp 1191-1198

[4] Elias, E., Okoth, P.F., Smaling, E.M.A. Explaining bread wheat (Triticum aestivum) yield differences by soil properties and fertilizer rates in the highlands of Ethiopia Geoderma 339, 2019, pp 126-133

[5] Gerhardt, N., Schwolow, S., Rohn, S, Arce, L., Weller, P. Quality assessment of olive oils based on temperature-ramped HS-GC-IMS and sensory evaluation: Comparison of different processing approaches by LDA, kNN, and SVM Food Chemistry 278, 2019, pp 720-728

[6] Hallmann, E., Marszałek, K., Lipowski, J., Średnicka-Tober, D., Rembiałkowska, E. Polyphenols and carotenoids in pickled bell pepper from organic and conventional production Food Chemistry 278, 2019, pp 254-260

[7] Hwang, J., Chung, J.-E. What drives consumers to certain retailers for organic food purchase: The role of fit for consumers' retail store preference, Journal of Retailing and Consumer Services 47, 2019, pp 293-306

[8] Iweala, S., Spiller, A., Meyerding, S. Buy good, feel good? The influence of the warm glow of giving on the evaluation of food items with ethical claims in the U.K. and Germany, Journal of Cleaner Production 215, 2019, pp 315-328

[9] Jiménez-Arias, D., García-Machado, F.J., Morales-Sierra, S., Valdés, F., Borges, A.A. Lettuce plants treated with L-pyroglutamic acid increase yield under water deficit stress, Environmental and Experimental Botany 158, 2019, pp 215-222

[10] Koppelmäki, K., Parviainen, T., Virkkunen, E., Schulte, R.P.O., Helenius, J. Ecological intensification by integrating biogas production into nutrient cycling: Modeling the case of Agroecological Symbiosis, Agricultural Systems 170, 2019, pp 39-48

[11] Meyerding, S.G.H., Bauchrowitz, A., Lehberger, M. Consumer preferences for beer attributes in Germany: A conjoint and latent class approach, Journal of Retailing and Consumer Services 47, 2019, pp 229-240

[12] Minton, E.A., Johnson, K.A., Liu, R.L. Religiosity and special food consumption: The explanatory effects of moral priorities, Journal of Business Research 95, 2019, pp 442-454

[13] Onrust, J., Piersma, T. How dairy farmers manage the interactions between organic fertilizers and earthworm ecotypes and their predators, Agriculture, Ecosystems and Environment 273, 2019, pp 80-85

[14] Petousi, I., Daskalakis, G., Fountoulakis, M.S, Stentiford, E.I., Manios, T. Effects of treated wastewater irrigation on the establishment of young grapevines, Science of the Total Environment 658, 2019, pp 485-492 
[15] Siedler, S., Balti, R., Neves, A.R. Bioprotective mechanisms of lactic acid bacteria against fungal spoilage of food, Current Opinion in Biotechnology 56, 2019, pp 138-146

[16] Su, X., Wu, F., Zhang, Y., Jin, Z., Xu, X. Effect of organic acids on bread quality improvement, Food Chemistry 278, 2019, pp 267-275

[17] Thøgersen, J., Pedersen, S., Aschemann-Witzel, J. The impact of organic certification and country of origin on consumer food choice in developed and emerging economies, Food Quality and Preference 72, 2019, pp. 10-30

[18] Tirloni, E., Stella, S., Bernardi, C., Dalgaard, P., Rosshaug, P.S. Predicting growth of Listeria monocytogenes in fresh ricotta, Food Microbiology 78, 2019, pp 123-133

[19] Upadhyay, M.K., Shukla, A., Yadav, P., Srivastava, S. A review of arsenic in crops, vegetables, animals and food products, Food Chemistry 276, 2019, pp 608-618

[20] Weidner, T., Yang, A., Hamm, M.W. Consolidating the current knowledge on urban agriculture in productive urban food systems: Learnings, gaps and outlook, Journal of Cleaner Production 209, 2019, pp 1637-1655

[21] Yin, S., Hu, W., Chen, Y., Wang, Y., Chen, M. Chinese consumer preferences for fresh produce: Interaction between food safety labels and brands, Agribusiness 35(1), 2019, pp 5368

[22] Zahedipour, P., Asghari, M., Abdollahi, B., Alizadeh, M., Danesh, Y.R. A comparative study on quality attributes and physiological responses of organic and conventionally grown table grapes during cold storage, Scientia Horticulturae 247, 2019, pp 86-95

[23] Anupama Sundar D, A Study of Consumer Behaviour on Repurchase Patronage of Diet Food Products. International Journal of Marketing and Human Resource Management, 8(4), 2017, pp. $29-42$

[24] N. Anil Kumar and Dr. Mridanish Jha, A Study on Attitude of Consumers Towards EcoFriendly Products. International Journal of Management, 8(3), 2017, pp. 116-126.

[25] Atul K. Shrivastava, Dr. S.K. Kumara Swamy, Anil Midathada and Uday K. Ravella Analysis of The Barriers for Implementing Green Supply Chain Management (GSCM) Practices on Organic Irrigation: An Analytical Hierarchy, Process (AHP) Approach. International Journal of Mechanical Engineering and Technology, 8(7), 2017, pp. 1465-1473.

[26] Ananda Vardhan Hebbani, Mridula Tripati, Veeresh A V, Mythreyi S Jamadagni, Chaitra M And Snehalatha Nadigar, Chaotropic Effects of Inorganic \& Organic Compounds on Bacteria - Influence on Gram Nature, International Journal of Advanced Research in Engineering and Technology (IJARET), Volume 4, Issue 7, November - December 2013, pp. 302-309 